\title{
Optimizing neural stem cell transfection with NeuroMag
}

\section{Protocol For: \\ High transfection efficiency of neural stem cells with magnetofection}

Cédric Sapet ${ }^{1}$, Nicolas Laurent ${ }^{1}$, Antoine de Chevigny² ${ }^{2}$, Loïc Le Gourrierec ${ }^{1}$, Elodie Bertosio ${ }^{1}$, Olivier Zelphati ${ }^{1}$, and Christophe Béclin²

${ }^{1}$ OZ Biosciences, Marseille, France and ${ }^{2}$ CNRS, IBDML-UMR-6216, Campus de Luminy, Marseille, France

BioTechniques Protocol Guide, January 2017; doi 10.2144/000114500

See full protocol online: https://benchtalk.biotechniques.com/users/8521-biotechniques-editors/posts/11622-protocol-for-optimizing-neural-stemcell-transfection-with-neuromag

Protocol Summary: Primary neural stem cells (NSCs) can be cultivated and differentiated in vitro but are difficult to transfect using conventional methods. We describe a simple and rapid magnetofectionbased method suitable for the lab bench as well as for high-throughput projects. Our method yields high transfection efficiency and can be used for deciphering the genetic control of neural cell differentiation.
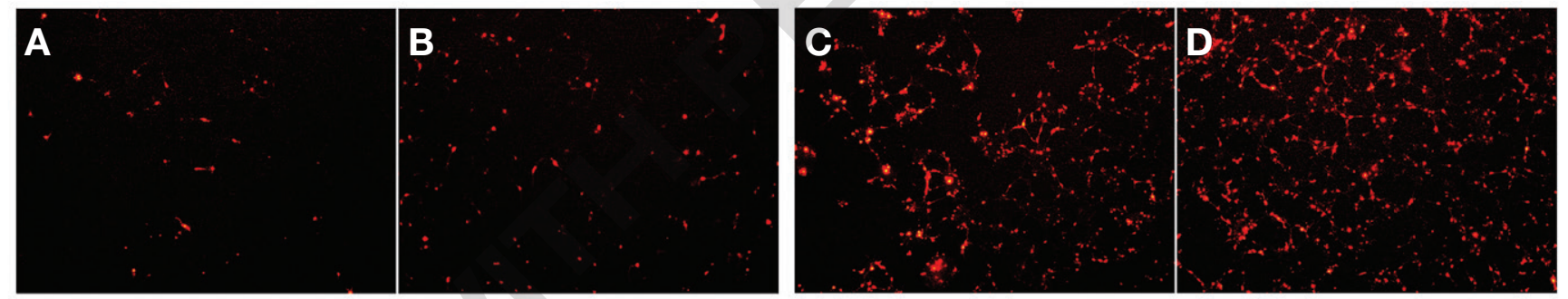

E
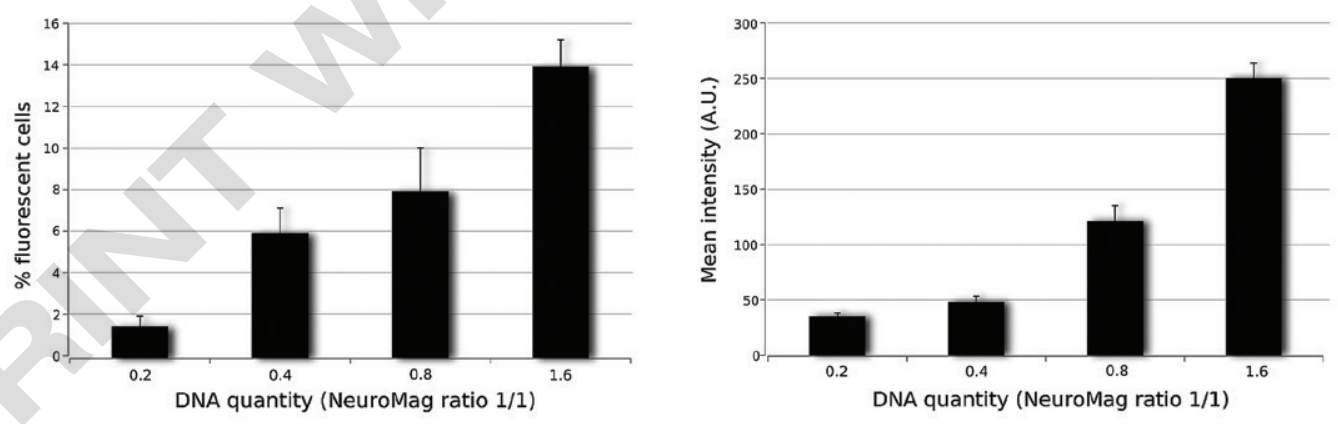

Protocol Schematic: Optimization of NeuroMag transfection efficiency in mouse NSCs. (A-D) Fluorescent images of Neural Stem Cells cultured in a 24-wells plate transfected with $0.2 \mathrm{~g}(\mathrm{~A}), 0.4 \mathrm{~g}(\mathrm{~B}), 0.8 \mathrm{~g}(\mathrm{C})$, and 1.6 $g$ (D) DsRed plasmid mixed with NeuroMag reagent in a 1:1 ratio. (E) Percentage of GFP-positive cells (upper graph) and mean fluorescence intensity (lower graph) 2 days after transfection with different amounts of DNA/ NeuroMag complexes at a 1:1 ratio. For transfection, NeuroMag reagent was mixed with DNA in a volume of culture medium of $50 \mu \mathrm{L}$ per transfected well. Complexes of magnetic nanoparticles and DNA were allowed to form via $15 \mathrm{~min}$ of incubation at room temperature before addition into the wells. The culture plate was then placed on a magnet for $15 \mathrm{~min}$. Cells were incubated in the presence of NeuroMag for 1 day before changing the medium. 